\title{
Genome-wide transcriptional analysis of temperature shift in L. interrogans serovar lai strain 5660 I
} Jin-Hong Qin ${ }^{1,2}$, Yue-Ying Sheng'2, Zhi-Ming Zhang3, Yao-Zhou Shi' ${ }^{3}$, Ping $\mathrm{He}^{2}$, Bao-Yu Hu${ }^{2}$, Yang Yang ${ }^{2}$, Shi-Gui Liu${ }^{1}$, Guo-Ping Zhao*3 and XiaoKui Guo*2

Address: ${ }^{1}$ School of Life Science/Chemical Engineering, Sichuan University, Chengdu 610041, PR China, ${ }^{2}$ Department of Microbiology and Parasitology, Shanghai Jiao Tong University School of Medicine, Shanghai 200025, PR China and ${ }^{3}$ National Engineering Center for Biochip at Shanghai, 151 Libing Road, Zhangjiang Hi-Tech Park, Pudong, Shanghai 201203, China

Email: Jin-Hong Qin - Jinhongq@hotmail.com; Yue-Ying Sheng - SHENG-kyq_1108@hotmail.com; ZhiMing Zhang - zhiming_zhang@shbiochip.com; Yao-Zhou Shi - xkguo@shsmu.edu.cn; Ping He - hpatsh@hotmail.com; BaoYu Hu - xkguo@shsmu.edu.cn; Yang Yang - gpzhao@sibs.ac.cn; Shi-Gui Liu - xkguo@shsmu.edu.cn; Guo-Ping Zhao* - gpzhao@sibs.ac.cn; Xiao-Kui Guo* -xkguo@shsmu.edu.cn

* Corresponding authors

Published: 09 June 2006

BMC Microbiology 2006, 6:5 I doi:|0.|| |86/|47|-2|80-6-5|
Received: 24 January 2006

Accepted: 09 June 2006

This article is available from: http://www.biomedcentral.com/I47I-2/80/6/5 I

(C) 2006 QIN et al; licensee BioMed Central Ltd.

This is an Open Access article distributed under the terms of the Creative Commons Attribution License (http://creativecommons.org/licenses/by/2.0), which permits unrestricted use, distribution, and reproduction in any medium, provided the original work is properly cited.

\begin{abstract}
Background: Leptospira interrogans is an important mammalian pathogen. Transmission from an environmental source requires adaptation to a range of new environmental conditions in the organs and tissues of the infected host. Several studies have shown that a shift in culture temperature from $28^{\circ} \mathrm{C}$ to $37^{\circ} \mathrm{C}$, similar to that encountered during infection of a host from an environmental source, is associated with differential synthesis of several proteins of the outer membrane, periplasm and cytoplasm. The whole genome of the Leptospira interrogans serogroup Icterohaemorrhagiae serovar lai type strain \#5660I was sequenced in 2003 and microarrays were constructed to compare differential transcription of the whole genome at $37^{\circ} \mathrm{C}$ and $28^{\circ} \mathrm{C}$.

Results: DNA microarray analyses were used to investigate the influence of temperature on global gene expression in $L$. interrogans grown to mid-exponential phase at $28^{\circ} \mathrm{C}$ and $37^{\circ} \mathrm{C}$. Expression of 106 genes differed significantly at the two temperatures. The differentially expressed genes belonged to nine functional categories: Cell wall/membrane biogenesis genes, hemolysin genes, heat shock proteins genes, intracellular trafficking and secretion genes, two-component system and transcriptional regulator genes, information storage and processing genes, chemotaxis and flagellar genes, metabolism genes and genes with no known homologue. Real-time reverse transcriptionPCR assays confirmed the microarray data.
\end{abstract}

Conclusion: Microarray analyses demonstrated that $L$. interrogans responds globally to temperature alteration. The data delineate the spectrum of temperature-regulated gene expression in an important human pathogen and provide many new insights into its pathogenesis. 


\section{Background}

The leptospires are motile, helical bacteria constituting a physiologically unique genus of spirochetes that includes the saprophyte L. biflexa and the pathogen L. interrogans. Leptospirosis is a globally important zoonotic disease caused by pathogenic Leptospira species including L. alexanderi, L. borgpetersenii, L. interrogans sensu stricto, it L. kirschneri, L. noguchii, L. santarosai, L. weilii, L. fainei, L. inadai and $L$. meyeri [1]. It affects a wide range of mammalian hosts, including humans, horses, dogs, pigs, cattle and wildlife. Because of the large spectrum of animal species that serve as reservoirs, leptospirosis is considered to be the most widespread zoonotic disease [2]. Aside from warm-blooded animals, leptospires can also survive in swamps, streams and rivers and alkaline muds and soils [1]. Humans and other animals become infected through contact with urine-contaminated soil and water. When it infects warm-blooded animals, L. interrogans must differentially express virulence and other genes at temperatures ranging from roughly $25^{\circ} \mathrm{C}$ to $37^{\circ} \mathrm{C}$. Several in vitro studies have mimicked the temperature shift that L. interrogans encounters during infection of a host from an environmental source [3-5]. However, for practical reasons, such studies have been restricted to examination of relatively few proteins.

A more complete analysis of the adaptive responses occurring during the temperature shift will be invaluable for understanding L. interrogans transmission, expression of virulence and immune evasion, and for the potential identification of new vaccine candidates. For this purpose, DNA microarrays are being applied to survey globally the adaptive responses to temperature shift in L. interrogans. It is now feasible to construct microarrays for analysis of $L$. interrogans because the complete Leptospira interrogans serogroup Icterohaemorrhagiae serovar lai type strain \#56601 genome is available [6]. In this study, expression of differential genes at $37^{\circ} \mathrm{C}$ relative to $28^{\circ} \mathrm{C}$ was studied to elucidate the overall gene expression patterns in L. interrogans. The differentially expressed genes found in this study are likely to be expressed differentially during natural mammalian infection and thus provide insights into the infection mechanisms of $L$. interrogans.

\section{Results and discussion}

Entry of L. interrogans into a warm-blooded host is usually accompanied by an upshift in temperature. Specific genes are activated or repressed in the bacterial response to temperature elevation $[7,8]$. To assess gene expression in cultures grown at different temperatures, $L$. interrogans were cultivated to mid-log-phase at $28^{\circ} \mathrm{C}$, then passaged into fresh medium incubated either at the original culture temperature or shifted to $37^{\circ} \mathrm{C}$ (see additional file 4). RNA was isolated from $L$. interrogans that grew well at each temperature. In our present work, two independent cultures were prepared as biological replicates for RNA isolation for each test or reference condition.

\section{Microarray experiments}

Two genome sequences of $L$. interrogans serovar Lai and $L$. interrogans serovar Copenhageni have been released [6,9]. The average nucleotide identity between the two genomes is $95 \%$. The average nucleotide identity between pairs of predicted orthologous protein coding genes is 99\%. However, the serovar Lai genome has 4727 putative genes annotated while serovar Copenhageni has only 3667. It would appear that the serovar Copenhageni sequence has fewer putative structural genes than that of serovar Lai. However, this difference occurred mainly because the Copenhageni sequence contained no predicted coding sequences less than or equal to $150 \mathrm{bp}$ in length that lacked significant homologues. The serovar Lai genome has 718 predicted genes of this kind. Genes shorter than $150 \mathrm{bp}$ were indeed expressed according to proteomics analysis (Ren et al., not published). Also, among the genes $180 \mathrm{bp}$ or more in length, 118 are unique to serovar Lai and 64 to serovar Copenhageni [10]. The 3528 ORFs spotted on the microarrays represented most of the genes more than $150 \mathrm{bp}$ in length (excluding the unique genes) in both serovars Lai and Copenhageni. Two independent experiments demonstrated that, on average, transcripts of $93 \%$ of all genes on the microarrays were detected in the mid-log phase of L. interrogans. Data from two independent experiments showed that transcripts of 101 genes were absent under both temperature conditions; these genes seemed not to be expressed at either $28^{\circ} \mathrm{C}$ or $37^{\circ} \mathrm{C}$ (see additional file 1).

\section{Intrachip and interchip reproducibility}

To evaluate intrachip and interchip reproducibility, we analyzed the expression values of three copies of all genes at various positions on each of two genechips. After some spots were excluded ( $\mathrm{SN}<2$, flag spots), the correlation coefficients $\mathrm{R}^{2}$ of the $\log _{2}$ (ratio) for three different copies of the gene were $0.824,0.817,0.837$ for one chip and $0.823,0.827,0.878$ for another. The correlation coefficient $\mathrm{R}^{2}$ of $\log _{2}$ (ratio) for the two chips (experiment-toexperiment reproducibility) was 0.665 . These results show good chip reproducibility (see also additional file 2).

\section{Verification of the microarray data}

The microarray transcription data were verified by realtime PCR assays of the same sample of 9 genes representing the upregulated, downregulated and unchanged genes (Fig. 1). The log-transformed change in relative quantity of mRNA between each test and reference condition was calculated for each gene. The correlation coefficient $\mathrm{R}^{2}$ between the data obtained by the two techniques was 0.8267 (Fig. 2). Although the fold change in gene expres- 


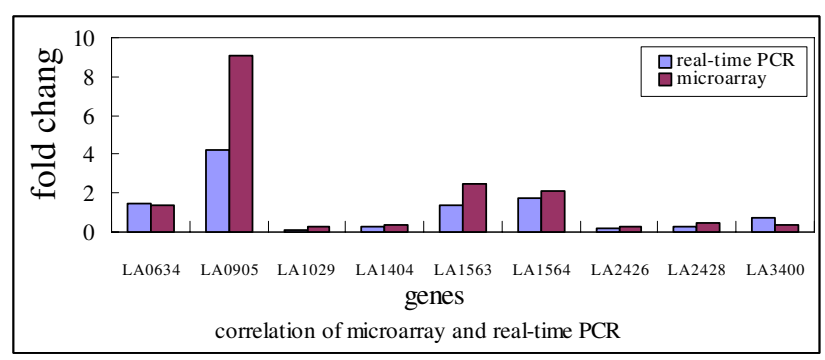

Figure I

correlation of microarray and Real-time PCR. Comparison of transcription measurements by microarray (red bar) and real-time PCR assays (blue bar). The fold change ratios are shown for nine genes at $37^{\circ} \mathrm{C}$ compared with $28^{\circ} \mathrm{C}$.

sion differed between the microarray and real time PCR results, the general trends were consistent. The real time PCR results therefore corroborated the microarray results but demonstrated the need for confirmation (see also additional file 3 ).

\section{Classification of temperature-related genes}

Temperature shift has been reported to alter protein synthesis in L. interrogans $[3,4,11,12]$. In order to characterize these changes at the global genome level, L. interrogans was cultured at different temperatures to mid-log-phase and gene expression was quantified. The scanned data generated from Tiffsplit software were imported into GeneSpring 4.0 software for further analysis. Fold change analysis was used to evaluate differential gene expression. The data showed that several genes were induced after temperature shift from $28^{\circ} \mathrm{C}$ to $37^{\circ} \mathrm{C}$; expression of 106 genes was at least twice as high in organisms grown at $37^{\circ} \mathrm{C}$ as in those grown at $28^{\circ} \mathrm{C}$ (Fig. 3 and Tables 1,2 ).

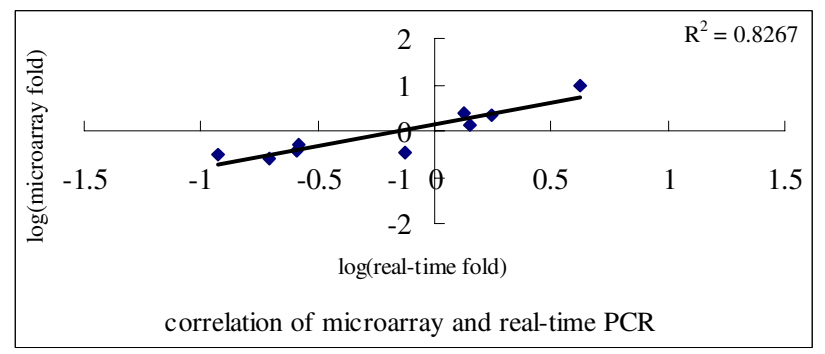

\section{Figure 2}

Comparison of transcription measurements by microarray and real-time $\mathbf{P C R}$ assays. The relative transcriptional levels for the 9 genes listed in Figure I were determined by microarray and real-time RT-PCR. The realtime RT-PCR $\log _{2}$ values were plotted against the microarray data $\log _{2}$ values. The correlation coefficient $\left(R^{2}\right)$ between the two datasets is 0.8267 .
Upregulation was apparent in 24 genes (Table 1) and downregulation in 82 (Table 2). Fewer genes were differentially regulated than in other temperature shift experiments $[13,14]$. The differentially expressed genes belonged to nine functional categories as shown in Fig 3. Many but not all of these categories contained both upregulated and downregulated genes. Among the upregulated candidates were hsp20 heat shock proteins genes, cell wall/membrane biogenesis genes, intracellular trafficking and secretion genes and information storage and processing genes. Unexpectedly, most of the upregulated genes were of unassigned function. Downregulated genes were more numerous and were represented in more categories than upregulated genes. They include pathogenic genes (including those for chemotaxis and motility), cell wall/ membrane biogenesis genes, signal transduction mechanism genes and metabolism genes. The fact that more genes are downregulated at $37^{\circ} \mathrm{C}$ than at $28^{\circ} \mathrm{C}$ might partly explain why $L$. interrogans grows more slowly at the higher temperature. Taken together, the data suggest that the composition of the L. interrogans proteome is substantially influenced by temperature.

\section{Heat shock protein genes}

In contrast to classical heat shock studies, our observations are based on shifting cultures from $28^{\circ} \mathrm{C}$ to $37^{\circ} \mathrm{C}$ and growing them for several days, simulating conditions that would be encountered during the infection of hosts from environmental sources. Typically, two major Hsps, GroEL and DnaK (members of the Hsp60 and Hsp70 families, respectively), are of considerable importance in the immunology and pathology of various bacterial and parasitic infections. No differences between the expression levels of DnaK and GroEL in L. interrogans maintained at $28^{\circ} \mathrm{C}$ and those shifted from $28^{\circ} \mathrm{C}$ to $37^{\circ} \mathrm{C}$ were detected in our study. The same results in protein expression were also reported by Jarlath E. Nally [4,11]. However, two other small heat shock genes (LA1563 and LA1564) (Table 1) belonging to the Hsp20 family showed increased expression when the organisms were cultured at $37^{\circ} \mathrm{C}$ for several days. Some studies have shown that low molecular mass heat shock proteins (HSPs) appear to act as molecular chaperones $[15,16]$. Others have shown that members of the Hsp20 family protect effectively against stress [17]. For example, in Babesia bovis, Hsp20 proteins are involved in the cellular response to stress. When the temperature was increased, Hsp20 expression was upregulated [18]. There have been no reports of temperaturerelated changes in expression of these two proteins in $L$. interrogans. The present result shows that these two Hsp20s play an important role in the response to temperature shift in L. interrogans. 


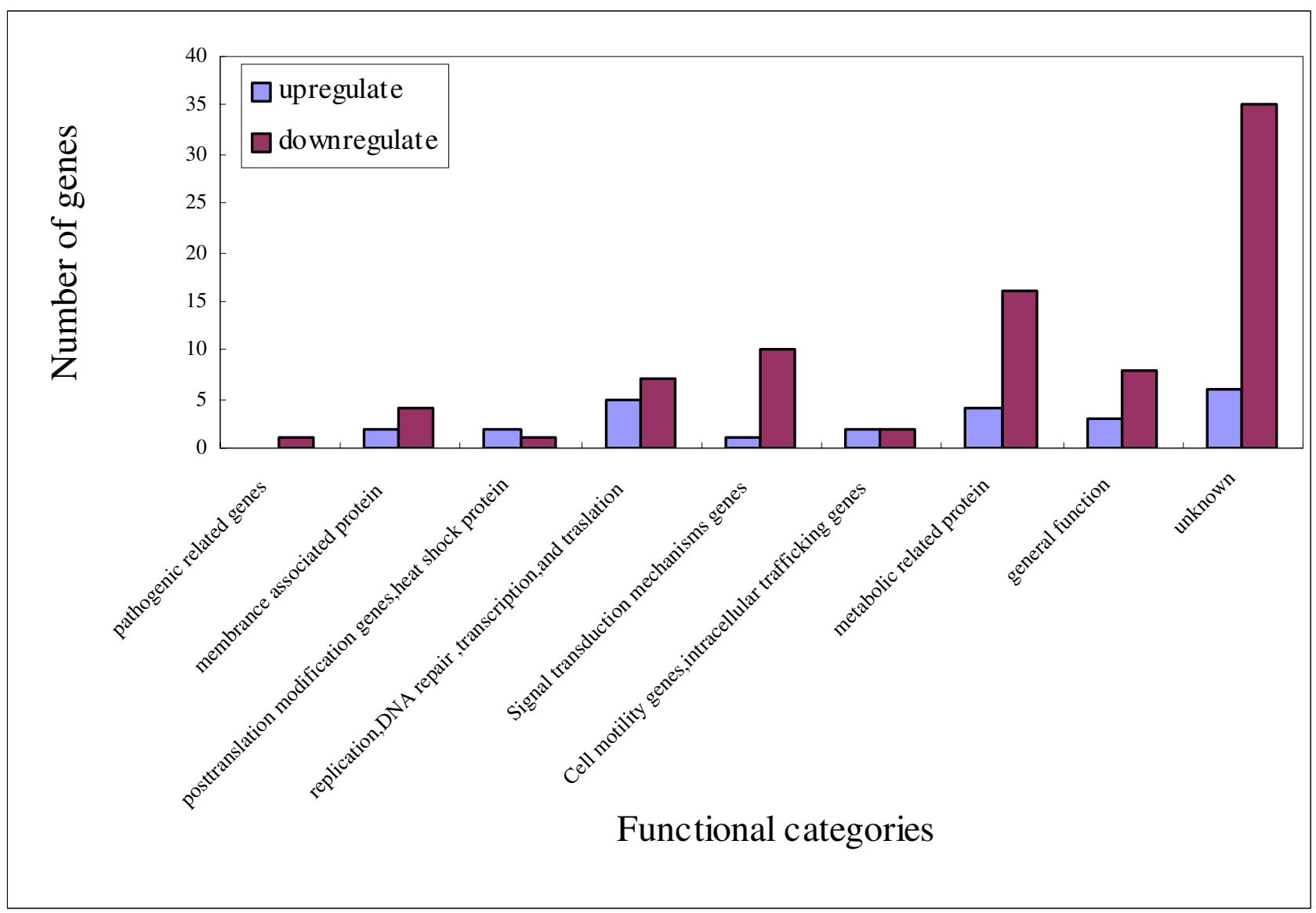

\section{Figure 3}

functional categories. Genes differentially expressed at $37^{\circ} \mathrm{C}$ and $28^{\circ} \mathrm{C}$, grouped by functional classification according to the $\mathrm{NCBI}$ L. interrogans 5660 I COGs database http://www.ncbi.nlm.nih.gov. Genes were regarded as differentially expressed when the expression levels differed by at least twofold. The number of upregulated (red bars) and downregulated (blue bars) genes in each functional group is shown.

\section{Membrane protein genes}

Membrane proteins, especially outer membrane proteins, are critical for understanding the interactions of bacteria with their environments and are the main candidates for protective antigens in extracellular pathogens. Many membrane proteins play an essential role in the development of new immunoprotection and serodiagnosis strategies [19]. Therefore, many studies have been focused on membrane proteins [20-22]. A recent surfaceome study of Leptospira showed that the expression of constituents remained unchanged under temperature changes [21]. The microarray data showed the same result. The genes for only six membrane-associated proteins were differentially expressed during culture at $37^{\circ} \mathrm{C}$ relative to $28^{\circ} \mathrm{C}$. Two (LA3927 and LA1203) was upregulated and four (LA2200, LA2248, LA4232 and LA1404) were downregulated at $37^{\circ} \mathrm{C}$ relative to $28^{\circ} \mathrm{C}$. LA3927 is one of two orthologues of the type I secretion TolC protein in L. interogans, which is a outer membrane channel protein playing a role in the secretion of extracellular hemolysins and enzymes [10]. Studies on other bacteria have shown that TolC in association with other membrane proteins exports a wide variety of drugs and toxic compounds [23]. In Vibrio alginolyticus, TolC is a stress-responsive protein [12]. It seems that increasing tolC expression in L. interrogans may be associated with virulence and with changes in export and other aspects of metabolism in response to the temperature shift. Another three downregulated membrane protein genes with no assigned function should be further studied to establish their physiological role in $L$. interrogans. 
Table I: Genes upregulated at least twofold at $37^{\circ} \mathrm{C}$ relative to $28^{\circ} \mathrm{C}$

\begin{tabular}{|c|c|c|c|}
\hline \multirow[t]{2}{*}{ Gene ID } & \multirow[t]{2}{*}{ Gene function and name } & \multicolumn{2}{|c|}{ Fold change in } \\
\hline & & Expt I & Expt2 \\
\hline \multicolumn{4}{|c|}{ Cell wall/membrane biogenesis genes } \\
\hline LAI 203 & alginate o-acetyltransferase & 2.393 & 2.084 \\
\hline LA3927 & Outer membrane protein tolC precursor & 3.337 & 3.817 \\
\hline \multicolumn{4}{|c|}{ Posttranslational modification, heat shock proteins genes } \\
\hline LAI 563 & class II heat shock protein (HSP20) & 2.439 & 4.233 \\
\hline LAI564 & class II heat shock protein (HSP20) & 2.142 & 2.859 \\
\hline \multicolumn{4}{|c|}{ replication, DNA repair, transcription and translation genes } \\
\hline LA0877 & Probable RNA polymerase ECF-type sigma factor & 4.704 & 4.752 \\
\hline LA0878 & DshA protein & 3.305 & 3.076 \\
\hline LA2204 & hypothetical protein & 2.027 & 3.693 \\
\hline LA3749 & hypothetical protein & 2.200 & 4.771 \\
\hline LA0065 & DNA-damage-inducible protein $\mathrm{F}$ & 2.356 & 2.028 \\
\hline \multicolumn{4}{|c|}{ Signal transduction mechanism genes } \\
\hline LA2549 & Sensory transduction histidine kinase & 3.174 & 2.309 \\
\hline \multicolumn{4}{|c|}{ intracellular trafficking and secretion genes } \\
\hline LA0905 & hypothetical protein & 9.108 & 7.718 \\
\hline LA3927 & Outer membrane protein tolC precursor & 3.337 & 3.817 \\
\hline \multicolumn{4}{|c|}{ metabolism genes } \\
\hline LA0633 & Probable peptide transporter permease & 2.441 & 2.025 \\
\hline LA3498 & Phosphate transport system protein phoU & 2.934 & 4.779 \\
\hline LA0430 & hypothetical protein & 7.594 & 4.995 \\
\hline LAI 889 & Putative I-aminocyclopropane-I-carboxylate deaminase & 2.692 & 2.519 \\
\hline \multicolumn{4}{|c|}{ general function } \\
\hline LA0297 & CBS domain protein & 2.464 & 2.200 \\
\hline LA0450 & conserved hypothetical protein & 2.631 & 2.244 \\
\hline LA0700 & hypothetical protein & 3.174 & 2.309 \\
\hline \multicolumn{4}{|l|}{ unknown } \\
\hline LA2440 & hypothetical protein & 2.309 & 2.956 \\
\hline LA2727 & unknown protein & 2.212 & 2.030 \\
\hline LA0430 & hypothetical protein & 7.594 & 4.995 \\
\hline LAI809 & conserved hypothetical protein & 2.155 & 2.882 \\
\hline LA2465 & unknown protein & 2.284 & 3.392 \\
\hline LA2764 & hypothetical protein & 6.620 & 7.058 \\
\hline LA4I9I & hypothetical protein & 2.063 & 2.936 \\
\hline
\end{tabular}

\section{Hemolysins encoded genes}

The primary lesion caused by Leptospira is damage to the endothelia of small blood vessels, leading to haemorrhage and localized ischaemia in multiple organs. As a consequence, renal tubular necrosis, hepatocellular damage, meningitis and myositis may occur in the infected host $[1,24]$. Hemolysins may play a fundamental role in this process [24]. Several hemolysin genes have been identified in the $L$. interrogans genome. We therefore determined whether these genes (LA0327, LA0378, LA1027, LA1029, LA1650, LA3050, LA3937 and LA4004) were differentially expressed at $37^{\circ} \mathrm{C}$ relative to $28^{\circ} \mathrm{C}$. Interestingly, one hemolysin gene (LA1029) encoding sphingomyelinase $\mathrm{C}$ was downregulated at the higher temperature, but the other hemolysin genes showed unchanged expression. The mechanism of regulation of these genes is not well understood and there have been no previous studies on their response to temperature shifts, so it will be interesting to conduct further studies on their regulation at different temperatures.

\section{Motility and chemotaxis genes}

Motility and chemotaxis are believed to be important in pathogenesis by many bacteria [25]. Motility and chemotaxis responses enable many pathogenic leptospires to penetrate host tissue barriers during infection and adapt to a variety of environments and hosts $[6,10,26]$. Chemotaxis has been extensively studied in the model organism Escherichia coli. E. coli encodes several chemoreceptors that sense environmental conditions and relay this information to a histidine kinase, CheA, through the coupling protein $\mathrm{CheW}$. CheA phosphorylates the response regulator $\mathrm{CheY}$, which in turn interacts with the flagellar motor in its phosphorylated form, altering both the direction of flagellum rotation and the swimming path of the bacterium [27]. Comparison of the complete sequences sug- 
Table 2: Genes downregulated at least twofold at $37^{\circ} \mathrm{C}$ relative to $28^{\circ}$

\begin{tabular}{|c|c|c|c|}
\hline \multirow[t]{2}{*}{ Gene ID } & \multirow[t]{2}{*}{ Gene function and name } & \multicolumn{2}{|c|}{ Fold change in } \\
\hline & & Exptl & Expt2 \\
\hline \multicolumn{4}{|c|}{ pathogenic genes } \\
\hline LAI029 & Sphingomyelinase $C$ precursor & 0.318 & 0.181 \\
\hline \multicolumn{4}{|c|}{ Cell wall/membrane biogenesis genes } \\
\hline LA2248 & putative outer membrane protein & 0.473 & 0.405 \\
\hline LA2200 & putative $\mathrm{N}$-acetylmuramoyl-L-alanine amidase & 0.20 & 0.278 \\
\hline LA4232 & conserved hypothetical protein & 0.413 & 0.383 \\
\hline LAI404 & putative outer membrane protein & 0.394 & 0.350 \\
\hline \multicolumn{4}{|c|}{ Posttranslational modification, heat shock proteins genes } \\
\hline LA3562 & conserved hypothetical protein & 0.457 & 0.450 \\
\hline \multicolumn{4}{|c|}{ replication, DNA repair, transcription and translation genes } \\
\hline LBII2 & putative regulatory protein contains GAF domain & 0.491 & 0.395 \\
\hline LB367 & hypothetical protein & $0.4 \mid 4$ & 0.285 \\
\hline LA2774 & conserved hypothetical protein & 0.380 & 0.423 \\
\hline LA4236 & MutS-like mismatch repair protein, ATPases & 0.297 & 0.265 \\
\hline LA30II & Cell division protein ftsK homologue & 0.397 & 0.469 \\
\hline LA0937 & hypothetical protein & 0.447 & 0.429 \\
\hline LA34I9 & DNA-directed RNA polymerase, beta subunit & 0.327 & 0.37 \\
\hline \multicolumn{4}{|c|}{ Signal transduction mechanism genes } \\
\hline LAI483 & GGDEF domain protein & 0.481 & 0.456 \\
\hline LA2423 & two-component response regulator & 0.479 & 0.471 \\
\hline LA2426 & Methyl-accepting chemotaxis protein & 0.260 & 0.197 \\
\hline LA2427 & Chemotaxis protein chew & 0.450 & 0.335 \\
\hline LA2434 & probable anti-sigma factor antagonist & 0.483 & 0.378 \\
\hline LA3 107 & unknown protein & 0.185 & 0.153 \\
\hline LBII2 & putative regulatory protein contains GAF domain & 0.491 & 0.395 \\
\hline LA3950 & hypothetical protein & 0.462 & 0.465 \\
\hline LA3357 & Sensory transduction histidine kinase & 0.465 & 0.474 \\
\hline LA4I04 & two-component hybrid sensor and regulator & 0.455 & 0.450 \\
\hline \multicolumn{4}{|c|}{ Chemotaxis and flagellar genes } \\
\hline LA2426 & Methyl-accepting chemotaxis protein & 0.260 & 0.197 \\
\hline LA2427 & Chemotaxis protein chew & 0.450 & 0.335 \\
\hline \multicolumn{4}{|c|}{ metabolism genes } \\
\hline LA0I06 & long-chain-fatty-acid CoA ligase & 0.463 & 0.442 \\
\hline LA0828 & Acetyl-CoA acetyl transferases & 0.469 & 0.332 \\
\hline LAI 430 & 3-oxoacyl-[acyl-carrier-protein] synthase & 0.493 & 0.356 \\
\hline LA2008 & hydrolipoamide acetyltransferase component of pyruvate dehydrogenase complex & 0.469 & 0.332 \\
\hline LA2009 & pyruvate dehydrogenase EI component, beta subunit & 0.451 & 0.371 \\
\hline LA2010 & pyruvate dehydrogenase EI component, alpha subunit & 0.486 & 0.435 \\
\hline LAI485 & mRNA-binding proteins & 0.278 & 0.436 \\
\hline LA2724 & hypothetical protein & 0.116 & 0.320 \\
\hline LA3 I 68 & hypothetical protein & 0.280 & 0.230 \\
\hline LA4I76 & conserved hypothetical protein & 0.480 & 0.448 \\
\hline LA4233 & hypothetical protein & 0.294 & 0.190 \\
\hline LA33I 2 & glyoxalase & 0.497 & 0.436 \\
\hline LA3628 & anthranilate synthase component I & 0.364 & 0.403 \\
\hline LA3998 & cholesterol oxidase & 0.381 & 0.358 \\
\hline LA4349 & putative peptidase & 0.437 & 0.349 \\
\hline LB093 & probable long-chain-fatty-acid - CoA ligase & 0.338 & 0.296 \\
\hline \multicolumn{4}{|c|}{ general function } \\
\hline LA0827 & hypothetical protein & 0.332 & 0.410 \\
\hline LAI 920 & RNA-binding protein & 0.301 & 0.0823 \\
\hline LA2724 & hypothetical protein & 0.116 & 0.320 \\
\hline LA3168 & hypothetical protein & 0.280 & 0.230 \\
\hline LA3400 & processing proteinase & 0.350 & 0.491 \\
\hline LA3998 & cholesterol oxidase & 0.381 & 0.358 \\
\hline LB265 & conserved hypothetical protein & 0.369 & 0.376 \\
\hline LA3584 & TPR-repeat-containing protein & 0.0539 & 0.159 \\
\hline
\end{tabular}


Table 2: Genes downregulated at least twofold at $37^{\circ} \mathrm{C}$ relative to $28^{\circ}$ (Continued)

\begin{tabular}{|c|c|c|c|}
\hline LA009I & conserved hypothetical protein & 0.444 & 0.441 \\
\hline LA2259 & conserved hypothetical protein & 0.362 & 0.358 \\
\hline LA3196 & conserved hypothetical protein & 0.239 & 0.200 \\
\hline LAI03I & hypothetical protein & 0.223 & 0.476 \\
\hline LA0278 & hypothetical protein & 0.0698 & 0.376 \\
\hline LAI403 & hypothetical protein & 0.252 & 0.233 \\
\hline LAI468 & conserved hypothetical protein & 0.286 & 0.316 \\
\hline LAI 572 & conserved hypothetical protein & 0.391 & 0.359 \\
\hline LAI910 & hypothetical protein & 0.452 & 0.495 \\
\hline LAI973 & hypothetical protein & 0.399 & 0.398 \\
\hline LA2020 & hypothetical protein & 0.260 & 0.177 \\
\hline LA2624 & hypothetical protein & 0.462 & 0.472 \\
\hline LA2859 & unknown protein & 0.401 & 0.358 \\
\hline LA2946 & hypothetical protein & 0.370 & 0.103 \\
\hline LA3036 & hypothetical protein & 0.363 & 0.480 \\
\hline LA3083 & hypothetical protein & 0.412 & 0.272 \\
\hline LA3344 & hypothetical protein & 0.123 & 0.184 \\
\hline LA3452 & hypothetical protein & 0.326 & 0.378 \\
\hline LA4030 & hypothetical protein & 0.469 & 0.350 \\
\hline LA4046 & hypothetical protein & 0.490 & 0.450 \\
\hline LA4282 & hypothetical protein & 0.454 & 0.420 \\
\hline LB032 & hypothetical protein & 0.422 & 0.485 \\
\hline LB2 17 & hypothetical protein & 0.442 & 0.324 \\
\hline LB2 17 & hypothetical protein & 0.324 & 0.442 \\
\hline LB243 & hypothetical protein & 0.375 & 0.448 \\
\hline LB3 I 6 & unknown protein & 0.345 & 0.290 \\
\hline LAII 78 & hypothetical protein & 0.188 & 0.432 \\
\hline LAI306 & hypothetical protein & 0.395 & 0.388 \\
\hline LAI952 & hypothetical protein & 0.440 & 0.419 \\
\hline LA20I 3 & hypothetical protein & 0.262 & 0.243 \\
\hline LA2624 & hypothetical protein & 0.111 & 0.158 \\
\hline LA2720 & hypothetical protein & 0.190 & 0.458 \\
\hline LA2839 & hypothetical protein & 0.233 & 0.346 \\
\hline LA4095 & hypothetical protein & 0.377 & 0.341 \\
\hline LAI 800 & Hypothetical protein & 0.485 & 0.242 \\
\hline
\end{tabular}

gests that the L. interrogans genome contains a relatively large number of motility and chemotaxis genes and has a more complex chemotaxis system than E. coli $[6,10]$. It may be reflects the survival and adaptation of pathogenic Leptospira to a variety of environments and hosts by selected differential expression of different motility and chemotaxis genes. In our study, two chemotaxis genes (LA2426 and LA2427) encoding the chemotaxis protein chew and the methyl-accepting chemotaxis protein were downregulated at $37^{\circ} \mathrm{C}$ relative to $28^{\circ} \mathrm{C}$. Chemotaxis plays multiple roles in the adaptation of a bacterium to its environment, so the changes in these two chemotaxis genes may enable $L$. interrogans to adjust to environmental changes.

\section{Two-component systems and other regulator genes}

The Leptospira life cycle requires the ability to respond to a complex array of environmental conditions [1]. One mechanism for adaptation to changing environments is through two-component regulatory systems, a family of proteins that are widely distributed among many bacterial genera [28]. Two-component systems allow specific envi- ronmental signals to be detected through a sensor histidine kinase that is usually associated with the cell membrane. In many cases, signaling through a single twocomponent system results in a coordinated change in expression of multiple genes, the products of which play a role in adaptation to a particular environment [29]. This is the most common type of signal transduction system in bacteria and controls such diverse processes as gene expression, sporulation and chemotaxis [30]. In pathogenic bacteria, two-component regulatory systems can also control the up- and down-regulation of different virulence determinants [29]. In our study, LA2549, a twocomponent sensor, was upregulated and three two-components (LA2423, LA3357 and LA4104) were downregulated at $37^{\circ} \mathrm{C}$ relative to $28^{\circ} \mathrm{C}$. It is unknown whether these two-components regulate virulence production or only adaptation to the temperature shift, which is disadvantageous for organism growth. These changes in gene regulation might enable the organism to adapt to the hostile environment of the host. In addition to the two-component systems, one anti-sigma factor antagonist gene, two cyclic nucleotide genes containing the GGDEF motif 
and a GAF domain regulator gene were also down-regulated at $37^{\circ} \mathrm{C}$ relative to $28^{\circ} \mathrm{C}$. Cyclic nucleotides appear to have a major regulatory role in Leptospira species $[6,9,10]$. GGDEF-domain proteins are more commonly found in non-obligate parasitic bacteria than in obligate parasites, indicating their importance in responding to environmental signals [9]. GAF is a cGMP binding domain. $L$. interrogans may respond to the temperature shift through these regulators, thus controlling other physiological changes that are important in adapting to the environment.

\section{Energy and metabolism genes}

Bacteria respond quickly to environmental stimuli, so energy production and metabolism adjust rapidly to new growth conditions. Indeed, many genes related to these processes were upregulated and downregulated by the temperature shift from $28^{\circ} \mathrm{C}$ to $37^{\circ} \mathrm{C}$, as shown in Table 1 and Table 2.

\section{Conclusion}

In this study, cDNA microarrays covering 3528 genes were used to investigate temperature shift adaptation by means of whole genomic transcription analysis. This is the first study of whole genomic transcription using the L. interrogans cDNA-genechip based on the complete sequence.

Several global transcription analyses of bacterial responses to growth temperature variation have been published; e.g. E. coli [31], group A Streptococcus [14], B. subtilis [32], Campylobacter jejuni [33], Borrelia burgdorfer [34] and Mycoplasma pneumoniae [35]. Although temperature-regulated bacterial gene expression has been well described in L. interrogans $[3,4,11]$, our study delineates global gene expression changes in this organism in response to temperature changes.

Bacteria use multiple molecular strategies to alter gene expression in response to temperature change. Our microarray analyses demonstrated that $L$. interrogans responds globally to temperature alteration. Temperature-induced genes include heat shock proteins genes, Cell wall $/ \mathrm{mem}$ brane biogenesis genes, virulence genes, regulatory genes and unidentified proteins. Our data demonstrate that $L$. interrogans has the ability to alter gene transcription extensively in response to temperature during infection. Importantly, many of the genes that are differentially regulated in response to growth temperature encode proteins of unknown function, and thereby provide additional avenues for pathogenesis research.

\section{Methods}

\section{Bacterial strain, medium, and growth}

Isolates of Leptospira interrogans (serogroup Icterohaemorrhagiae, serovar lai, type strain 56601) were obtained from the Institute for Infectious Disease Control and Prevention (IIDC), Beijing, China. L. interrogans was grown in liquid Ellinghausen-McCullough-Johnson-Harris (EMJH) medium at $28^{\circ} \mathrm{C}$ under aerobic conditions to mid-logphase and then shifted to fresh EMJH medium incubated at $28^{\circ} \mathrm{C}$ or $37^{\circ} \mathrm{C}$ under aerobic conditions. Only mid-logphase cultures at a mean density of $10^{6} / \mathrm{ml}$ in $100 \mathrm{ml}$ were used in gene expression analysis experiments. The cells were harvested by centrifugation at $10,000 \mathrm{~g}$ for $10 \mathrm{~min}$ at $4^{\circ} \mathrm{C}$.

\section{RNA isolation}

For each condition $\left(37^{\circ} \mathrm{C}\right.$ and $\left.28^{\circ} \mathrm{C}\right)$, total RNA was extracted from two independent replicates. Cells were harvested and the complete RNAs were extracted using Trizol reagent (Invitrogen) according to the manufacturer's protocol. Contaminating DNA was digested with RQ1 RNasefree DNase (Promega Corp.). The treated RNAs were purified with a QIAGEN RNeasy Kit (QIAGEN). RNA quality was monitored by agarose gel electrophoresis, and the quantity was determined spectrophotometrically (Ependorf).

\section{Microarray hybridization}

Arrays of whole L. interrogans genome PCR products were based on the sequenced genomes of Leptospira interrogans serogroup Icterohaemorrhagiae serovar lai type strain \#56601. Of 4,727 total predicted genes, 3700 were incorporated (excluding the 1027 ORFs that are unique or are $150 \mathrm{bp}$ or less in length). Of these 3700 genes, PCRs for 172 consistently failed to yield satisfactory results (no product, product of the wrong size, multiple bands or faint bands), even after redesigned primers were used in the amplification reaction. Thus, 3528 ORFs were correctly amplified. PCR products were spotted on to poly-lysine-coated glass microarray slides with Genemachine. Probes were printed in triplicate on the slides as described in the manual. Each test RNA $\left(10 \mu \mathrm{g}\right.$, cultured at $\left.37^{\circ} \mathrm{C}\right)$ and reference RNA (10 $\mu \mathrm{g}$, cultured at $28^{\circ} \mathrm{C}$ ) was labeled with $\mathrm{Cy} 3$ or $\mathrm{Cy} 5$, respectively, by reverse transcription using Superscript (Invitrogen). The unincorporated dye was removed using a QIAquick Nucleotide Removal Kit (QIAGEN) as specified by the manufacturer's protocol. Samples were hybridized competitively under coverslips to the microarray slides at $42^{\circ} \mathrm{C}$ for $16 \mathrm{~h}$, and then washed as described in the manual. Hybridization experiments were performed in duplicate using cDNA derived from four different cultures of $L$. interrogans (two grown at $37^{\circ} \mathrm{C}$, two at $28^{\circ} \mathrm{C}$ ).

\section{Data analysis}

The hybridization slides were scanned and analyzed by Tiffsplit (Agilent) to calculate the signal intensities and to determine the presence or absence of each open reading frame. The microarrays were then normalized, and their backgrounds were defined using GeneSpring 4.0 (Silicon 
Genetics). The GeneSpring software was used to analyze the transcription patterns further. To identify genes with significantly altered expression levels for further analysis, cutoff values for expression level ratios 2.0 and 0.5 were used to filter genes with changes ( $\mathrm{n}$-fold) greater than \pm 2.0 in two independent biological samples, even though a 1.5 -fold cutoff has recently been reported as biologically significant $[14,33,36]$. Student's t test/analysis of variance was used to compare the mean expression levels of the test and reference samples. Genes with significant differential expression levels $(\mathrm{P}<0.05)$ were selected.

For intrachip and interchip reproducibility analysis, flagged spots or $\mathrm{SN}<2$ spots were excluded. The coefficients of three spots in same chip for each gene were calculated to estimate intrachip reproducibility using Microsoft Excel. The coefficient of an average of two independent biological samples was calculated to estimate interchip reproducibility.

For functional gene categories, most ORFs were taken from Genbank accession numbers NC004342 and NC004343 [37]. For annotation in GenBank as hypothetical and conserved proteins, Cluster of Orthologous Genes (COG) descriptions in NCBI were used [37]. Blast [38] was also used to identify whether homologues were present in other bacteria. Differentially transcribed genes were classified into functional groups by COG classification when available. Genes without COG classification were categorized by their GenBank annotations.

\section{Real-time quantitative PCR (qPCR)}

The RNA samples subjected to microarray analysis were also used to produce cDNA by reverse transcription using Superscript $\alpha$ (Invitrogen) to confirm changes in the expression of selected genes. qPCR was performed using the cDNAs as templates with a Roche real-time PCR machine (Roche) as described [39], using the SYBR green dye and Invitrogen kit (Invitrogen) according to the manufacture's protocol. For each amplification run, the calculated threshold cycle $(\mathrm{Ct})$ for each gene amplicon was normalized to the $\mathrm{C}_{t}$ of the $16 \mathrm{~S}$ rRNA gene amplified from the corresponding sample before the gene fold and relative changes were calculated as described $[39,40]$.

\section{Competing interests}

The author(s) declare that they have no competing interests.

\section{Authors' contributions}

JHQ and XKG designed the research project. JHQ, ZMZ and YYS constructed the microarray. JHQ, ZMZ and PH performed the microarray study and analyzed the data. JHQ, YY and BYH coordinated the Leptospira culture. JHQ and XKG drafted the manuscript. GPZ and SGL par- ticipated in the design of the study and helped to draft the manuscript. All authors contributed in the writing and preparation of the manuscript. All authors read and approved manuscript.

\section{Additional material}

\section{Additional File 1}

Microsoft Excel document, absent genes in two microarrays. This file and dataset contains 101 genes that that were not expressed whatever conditions $\left(28^{\circ} \mathrm{C}\right.$ and $\left.37^{\circ} \mathrm{C}\right)$ in our experiment.

Click here for file

[http://www.biomedcentral.com/content/supplementary/14712180-6-51-S1.xls]

\section{Additional File 2}

Microsoft Excel document, all genes contained in the two microarrays. This file provides a list of raw data of all the genes contained in the microarrays.

Click here for file

[http://www.biomedcentral.com/content/supplementary/14712180-6-51-S2.rar]

\section{Additional File 3}

Microsoft Excel document, nine genes contained in the microarrays and Real-time PCR.

Click here for file

[http://www.biomedcentral.com/content/supplementary/14712180-6-51-S3.xls]

\section{Additional File 4}

Microsoft Excel document, raw data and growth curve of $\mathrm{L}$. interrogans cultured at $37^{\circ} \mathrm{C}$ and $28^{\circ}$.

Click here for file

[http://www.biomedcentral.com/content/supplementary/14712180-6-51-S4.xls]

\section{Acknowledgements}

We thank Qing Zhang, Jia-Qi Xiao, Ke Dong, Zhen-Hong Li, Qing-Tian Li and Xiong-Zhang Zhu for helping in developing the experiment. This work was supported in part by the grants from the National Natural Science Foundation of China (No. 3037007 I \& 303001 97), the National High Technology Research and Development Program of China and Shanghai Leading Academic Discipline Project (T0206).

\section{References}

I. Faine S, Adler B, Bolin C, Perolat P: Leptospira and leptospirosis. Medisci, Melbourne, Australia; 1999.

2. Levett PN: Leptospirosis. Clin Microbiol Rev 200I, 14(2):296-326.

3. Jarlath E, Nally SA, Timoney John F: Molecular Characterization of Thermoinduced Immunogenic Proteins Q I p42 and Hsp I 5 of Leptospira interrogans. Infection and Immunity 200I, 69:7616-7624.

4. Nally JE, Timoney JF, Stevenson B: Temperature-regulated protein synthesis by Leptospira interrogans. Infect Immun 200I, 69(I):400-404.

5. Cullen PA, Cordwell SJ, Bulach DM, Haake DA, Adler B: Global analysis of outer membrane proteins from Leptospira interrogans serovar Lai. Infect Immun 2002, 70(5):23।I-23I8.

6. Ren SX, Fu G, Jiang XG, Zeng R, Miao YG, Xu H, Zhang YX, Xiong $H$, Lu G, Lu LF, Jiang HQ, jia J, Tu YF, jiang JX, Gu WY, Zhang YQ, 
Cai Z, Sheng HH, Yin HF, Zhang Y, Zhu GF, Wan M, Huang HL, Qian Z, Wang SY, Ma W, Yao ZJ, Shen Y, Qiang BQ, Xia QC, Guo XK, Danchin A, Saint GI, Somerville RL, Wen YM, Shi MH, Chen Z, Xu JG, Zhao GP: Unique physiological and pathogenic features of Leptospira interrogans revealed by whole-genome sequencing. Nature 2003, 422(6934):888-893.

7. Yura TKN: Regulation of the heat-shock response. Curr Opin Microbiol 1999, 2(2):53-158.

8. Gophna UEZR: Virulence and the heat shock response. Int J Med Microbiol 2 2003, 92(7-7):453-46I.

9. Nascimento AL, Verjovski-Almeida S, Van Sluys MA, MonteiroVitorello CB, Camargo LE, Digiampietri LA, Harstkeerl RA, Ho PL, Marques MV, Oliveira MC, Setubal JC, Haake DA, Martins EA: Genome features of Leptospira interrogans serovar Copenhageni. Braz J Med Biol Res 2004, 37(4):459-477.

10. Nascimento AL, Ko Al, Martins EA, Monteiro-Vitorello CB, Ho PL, Haake DA, Verjovski-Almeida S, Hartskeerl RA, Marques MV Oliveira MC, Menck CF, Leite LC, Carrer H, Coutinho LL, Degrave WM, Dellagostin OA, El-Dorry H, Ferro ES, Ferro MI, Furlan LR, Gamberini M, Giglioti EA, Goes-Neto A, Goldman GH, Goldman MH, Harakava R, Jeronimo SM, Junqueira-de-Azevedo IL, Kimura ET, Kuramae EE, Lemos EG, Lemos MV, Marino CL, Nunes LR, deOliveira RC, Pereira GG, Reis MS, Schriefer A, Siqueira WJ, Sommer P, Tsai SM, Simpson AJ, Ferro JA, Camargo LE, Kitajima JP, Setubal JC, Van Sluys MA: Comparative genomics of two Leptospira interrogans serovars reveals novel insights into physiology and pathogenesis. J Bacteriol 2004, I86(7):2164-2I72.

II. Stamm LV, Gherardini FC, Parrish EA, Moomaw CR: Heat shock response of spirochetes. Infect Immun I99I, 59(4): I572-I575.

12. Xu CWS, Ren H, Lin X, Wu L, Peng X: Proteomic analysis on the expression of outer membrane proteins of Vibrio alginolyticus at different sodium concentrations. Proteomics 2005, 5(12):3142-3152.

13. Han Y, Zhou D, Pang X, Song Y, Zhang L, Bao J, Tong Z, Wang J, Guo $Z$, Zhai J, Du Z, Wang X, Zhang X, Wang J, Huang P, Yang R: Microarray analysis of temperature-induced transcriptome of Yersinia pestis. Microbiol Immunol 2004, 48(I I):79I-805.

14. Smoot LM, Smoot JC, Graham MR, Somerville GA, Sturdevant DE, Migliaccio CA, Sylva GL, Musser JM: Global differential gene expression in response to growth temperature alteration in group A Streptococcus. Proc Natl Acad Sci USA 200I, 98:104|6-1042I.

15. Kanno Y, Matsuno H: The Possibility of Novel Antiplatelet Peptides: The Physiological Effects of Low Molecular Weight HSPs on Platelets. Curr Pharm Des 2006, I 2(7):887-892.

16. Horwitz J: Alpha-crystallin can function as a molecular chaperone. Proc Natl Acad Sci USA 1992, 89(2 I): 10449-10453.

17. Yan-hui ZHU T-mM, Xian WANG: Gene transfer of heat-shock protein 20 protects against ischemia/reperfusion injury in rat hearts. Acta Pharmacologica Sinica 2005, 26(10): I 193.

18. Lee S, Carson K, Rice-Ficht A, Good T: Hsp20, a novel alpha-crystallin, prevents Abeta fibril formation and toxicity. Protein Sci 2005, I 4(3):593-60I.

19. Zhang XY, Yu Y, He P, Zhang YX, Hu BY, Yang Y, Nie YX, jiang XG Zhao GP, Guo XK: Expression and comparative analysis of genes encoding outer membrane proteins LipL2I, LipL32 and OmpLI in epidemic leptospires. Acta Biochim Biophys Sin (Shanghai) 2005, 37(10):649-656.

20. Nally JE, Whitelegge JP, Aguilera R, Pereira MM, Blanco DR, Lovett $M A$ : Purification and proteomic analysis of outer membrane vesicles from a clinical isolate of Leptospira interrogans serovar Copenhageni. Proteomics 2005, 5(I): I 44-I52.

21. Cullen PA, Xu X, Matsunaga J, Sanchez Y, Ko Al, Haake DA, Adler B: Surfaceome of Leptospira spp. Infect Immun 2005 , 73(8):4853-4863.

22. Haake DA, Matsunaga J: Leptospiral membrane proteins - variations on a theme? Indian J Med Res 2005, I I I(3): I43- I 45.

23. Baucheron SMC, Praud K, Chaslus-Dancla E, Cloeckaert A: TolC but not AcrB is essential for multidrug-resistant Salmonella enterica serotype Typhimurium colonization of chicks. J Antimicrob Chemother 2005, 55(5):707-7I2.

24. Yi-xuan ZHANG YG, Bo BI, Jian-yong HE, Chun-fu WU, Xiao-kui GUO, Guo-ping ZHAO: Identification and classification of all potential hemolysin encoding genes and their products from Leptospira interrogans serogroup Icterohaemorrhagiae serovar Lai. Acta Pharmacologica Sinica 2005, 26(4):453.
25. Motaleb MAMM, Li C, Bakker RG, Goldstein SF, Silversmith RE, Bourret RB, Charon NW: CheX Is a Phosphorylated CheY Phosphatase Essential for Borrelia burgdorferi Chemotaxis. J Bacteriol 2005, I 87(23):7963-7969.

26. Charon NW, Goldstein SF: Genetics of motility and chemotaxis of a fascinating group of bacteria: the spirochetes. Annu Rev Genet 2002, 36:47-73.

27. Armitage JP: Bacterial tactic responses. Adv Microb Physiol 1999, 41:229-289.

28. Parkinson JS: Signal transduction schemes of bacteria. Cell 1993, 73(5):857-87|.

29. Jiang SM, Cieslewicz MJ, Kasper DL, Wessels MR: Regulation of virulence by a two-component system in group $B$ streptococcus. J Bacteriol 2005, 187(3): I 105-1 I I3.

30. Novick RP: Autoinduction and signal transduction in the regulation of staphylococcal virulence. Mol Microbiol 2003, 48(6): 1429-1449.

31. Richmond CS, Glasner JD, Mau R, Jin H, Blattner FR: Genome-wide expression profiling in Escherichia coli K-12. Nucleic Acids Res 1999, 27( ( 9):382 I-3835.

32. Helmann JD, Wu MF, Kobel PA, Gamo FJ, Wilson M, Morshedi MM, Navre M, Paddon C: Global transcriptional response of Bacillus subtilis to heat shock. J Bacteriol 200I, 183(24):7318-7328.

33. Stintzi A: Gene expression profile of Campylobacter jejuni in response to growth temperature variation. I Bacteriol 2003, I 85(6):2009-20|6

34. Ojaimi C, Brooks C, Casjens S, Rosa P, Elias A, Barbour A, Jasinskas A, Benach J, Katona L, Radolf J, Caimano M, Skare J, Swingle K, Akins D, Schwartz I: Profiling of temperature-induced changes in Borrelia burgdorferi gene expression by using whole genome arrays. Infect Immun 2003, 7 I(4): I689-I705.

35. Weiner J 3rd, Zimmerman CU, Gohlmann HW, Herrmann R: Transcription profiles of the bacterium Mycoplasma pneumoniae grown at different temperatures. Nucleic Acids Res 2003, 3 I(2I):6306-6320

36. Hughes TR, Marton MJ, Jones AR, Roberts CJ, Stoughton R, Armour CD, Bennett HA, Coffey E, Dai H, He YD, Kidd MJ, King AM, Meyer MR, Slade D, Lum PY, Stepaniants SB, Shoemaker DD, Gachotte D, Chakraburtty K, Simon J, Bard M, Friend SH: Functional discovery via a compendium of expression profiles. Cell 2000, 102:109-126.

37.

//www ncbinlm nih gov/entreg uery.fcgi?db=genome\&cmd=Retrieve\&dopt=Over view\&list uids $=258$.

38. [http://www.ncbi.nlm.nih.gov/BLAST/]

39. Schmittgen TD, Zakrajsek BA, Mills AG, Gorn V, Singer MJ, Reed MW: Quantitative reverse transcription-polymerase chain reaction to study mRNA decay: comparison of endpoint and real-time methods. Anal Biochem 2000, 285(2): 194-204.

40. Livak KJ, Schmittgen TD: Analysis of relative gene expression data using real-time quantitative PCR and the 2(-Delta Delta C(T)) Method. Methods 200I, 25(4):402-408

Publish with Bio Med Central and every scientist can read your work free of charge

"BioMed Central will be the most significant development for disseminating the results of biomedical research in our lifetime. "

Sir Paul Nurse, Cancer Research UK

Your research papers will be:

- available free of charge to the entire biomedical community

- peer reviewed and published immediately upon acceptance

- cited in PubMed and archived on PubMed Central

- yours - you keep the copyright
BioMedcentral 